Çukurova Üniversitesi Mühendislik Mimarlık Fakültesi Dergisi, 32(3), ss. 111-119, Eylül 2017

\title{
Tek ve İki Bina Etrafındaki Rüzgar Etkilerinin Sayısal Olarak İncelenmesi
}

\author{
Ahmet FERTELLi' ${ }^{* 1}$, Mehmet BALTA ${ }^{2}$ \\ ${ }^{1}$ Cumhuriyet Üniversitesi, Mühendislik Fakültesi, Makine Mühendisliği Bölümü, Sivas \\ ${ }^{2}$ Amasya Üniversitesi, Teknik Bilimler Meslek Yüksekokulu, Makine Bölümü, Amasya
}

Geliş tarihi: 03.03.2017～Kabul tarihi: 25.09.2017

\section{Öz}

$\mathrm{Bu}$ çalı̧̧mada, tek ve iki bina modeli için rüzgar yükünün etkileri sayısal olarak incelenmiştir. Bina modelleri etrafındaki akış alanları üç boyutlu ve zamandan bağımsız olarak FLUENT paket programı ile hesaplanmıştır. Sayısal çözümlemede Sivas ili için atmosferik sınır tabaka hız profili oluşturulmuş ve RNG k- $\varepsilon$ türbülans modeli kullanılmıștır. Analizler sonucunda akım çizgileri, hız vektörleri, ortalama hız ve türbülans kinetik enerji dağılımları ile model yüzeylerinde ortalama basınç katsayısı dağılımları hesaplanmıştır. İki bina düzenlemesi için negatif basınç katsayılarının tekli binadan daha yüksek olduğu görülmüştür.

Anahtar Kelimeler: Bina aerodinamiği, Basınç katsayısı, Rüzgâr yükü, Türbülans modeli

\section{Numerical Analysis of Wind Effect Around Single and Two Buildings}

\begin{abstract}
In this study, effects of wind load for the a single and two building arrangement is investigated numerically. Flow fields around building models are calculated by FLUENT software package in three dimension and independent of time. In numerical analysis the atmospheric boundary layer velocity profile was created for Sivas province and RNG k- $\varepsilon$ turbulence model was used. As a result of analysis, streamlines, velocity vectors, mean velocity and turbulence kinetic energy distribution and mean pressure coefficient the patterns of models were calculated. It is seen that the negative pressure coeefficients for the two-building arrangement is larger than that for the single building.
\end{abstract}

Keywords: Building aerodynamic, Pressure coefficient, Wind load, Turbulence model

"Sorumlu yazar (Corresponding author): Ahmet FERTELLİ, fertelli@ cumhuriyet.edu.tr 


\section{GíRiş}

Çok katlı binaların varlığı şehir yaşantısının bir parçası olarak hayatımızda yer almaktadır. Değişen yaşam koşulları sonucu belirli alanda birden fazla binanın yer aldığı yeni yaşam alanlarının sayısı her geçen gün artmaktadır. Bu değişim, binaların birbiri üzerindeki etkisinin araştırılmasını önemli hale getirmiştir. Bina rüzgâr etkileşimi sonucunda oluşan girdap grupları, binada titreşim ve gürültü oluşturmaktadır. Ayrıca bina üzerinde farklı büyüklüklerde basınç alanları oluşturan rüzgâr, binaların hasar görmesine neden olabilmektedir. Rüzgârın bu tür olumsuz etkileri, tasarım aşamasında yapılacak deneysel ve sayısal çalışmalar ile büyük ölçüde önlenebilir.

\section{2. ÖNCEKİ ÇALIŞMALAR}

Literatürde farklı bina geometrileri etrafindaki akış alanlarının incelenmesine yönelik çok sayıda deneysel ve sayısal çalışma mevcuttur. Blocken ve arkadaşları [1], birbirine paralel şekilde yerleştirilmiş olan binalar etrafindaki akışı incelemek ve farklı duvar koşullarının etkilerini görmek için $\mathrm{k}-\varepsilon$ türbülans modeli ile simülasyonlar yapmıştır. Çözüm ağında binalar etrafı yapısal, geri kalan hesaplama alanı için yapısal olmayan çözüm ağı kullanılmıştır. $\mathrm{Bu}$ çalışmanın sonucunda binalar arasındaki mesafe arttıkça akış tek bir bina etrafindaki gibi hareket ederken, birbirlerine yaklaştıkça karmaşık hareketler yaptığı belirlenmiştir. Özmen ve arkadaşları [2], atmosferik sınır tabaka içindeki farklı eğim açılarına sahip üçgen çatılı alçak katlı bina modelleri üzerinde türbülanslı akış alanları deneysel ve sayısal olarak incelemiştir. Çalışmada $90^{\circ}$ rüzgâr doğrultusunda $15^{\circ}, 30^{\circ}$ ve $45^{\circ}$ 'li çatı açılara sahip binalar kullanılmıştır. Yüzey ortalama basınç dağılımı $15^{\circ}$ 'lik çatı eğiminin, $30^{\circ}$ ve $45^{\circ}$ lik çatı eğimlerine göre çatılarda daha büyük bir emme kuvvetine neden olduğu tespit edilmiştir. Kaydok [3] kare kesite $\% 10, \% 20$ ve $\% 30$ oranda köşe boşaltma yaparak oluşturduğu yeni bina modelleri etrafindaki akış alanlarını farklı türbülans modelleriyle, üç boyutlu ve zaman bağımsız hesaplamıştır. Bina modellerinde geometrik değişimlerin akış alanlarında ve özellikle yüzey basınç dağılımlarında belirgin farklılıklara yol açtığını belirtmiştir. Hunte [4] kare kesitli bir yüksek bina modeli etrafındaki akışı deneysel olarak rüzgâr tünelinde, sayısal olarak ise üç boyutlu zamandan bağımsız çözümler ile incelemiştir. RSM ve Realizable k- $\varepsilon$ türbülans modellerini kullandığı sayısal çalışmada, RSM k- $\varepsilon$ türbülans modeli kullanarak elde ettiği basınç katsayısı değerlerinin deneysel verilerle daha uyumlu olduğunu belirtmiştir. Ayrıca, yüzey pürüzlülük değerlerinin bina üzerinde oluşan basınç katsayılarına önemli ölçüde bir etkisi olmadığını belirtmiştir. Tutar ve Oğuz [5], yan yana farklı mesafelerde yerleştirdiği ikili bina modelleri etrafindaki akış alanını farklı türbülans modelleri ile incelemiştir. İki bina arası mesafenin artması vorteks kuvvetlerinde azalmaya sebep olduğu sonucunu ortaya koymuşlardır. Kanbur ve arkadaşları [6], İstanbul'da yüksek katlı binalara etkiyen rüzgâr yüklerinin etkileri incelenerek, yüksek ve alçak katlı binaların rüzgârdan dolayı olan etkileşimleri sayısal olarak gözlemlemiştir. İncelemede Ansys Fluent paket programı kullanılmış olup, analiz sonucunda, binaların çevresindeki bölgelerde türbülans kinetik enerji, basınç ve hız değişimlerinde meydana gelen değişimlerin kaynağı yorumlanmıştır. Gousseau ve arkadaşları [7], kirlilik dağılımını incelemek üzere bir grup bina modelleri ile rüzgâr tüneli testleri yapmıştır. Reynolds Ortalama Navier-Stokes (RANS) ve Large Eddy Simulation (LES) türbülans modelleri ile yapılan sayısal çalışma rüzgâr tüneli deneyinin uyumlu olduğu görülmüştür. Braun ve arkadaşları [8], "Standart CAARC Binası" üzerindeki aerodinamik ve aeroelastik karakteristikleri belirleyebilmek amaciyla LES türbülans modeli kullanarak sayısal çözümler gerçekleştirmişlerdir. Bina etrafındaki akış karakteristiklerini ve bina yüzeylerindeki basınç dağılımlarını inceledikleri çalışmada elde ettikleri sayısal sonuçların literatürde mevcut deneysel verilerle oldukça iyi bir uyum sağladıklarını vurgulamışlardır. Nozawa ve Tamura [9] türbülanslı akış altında bir bina etrafında farklı durumlar için akış incelemiştir. Düzgün ve pürüzlü yüzeylerde farklı türbülans şiddetlerinin $(\% 8, \% 14, \% 26)$ basınç katsayılarının dağılımına etkisi incelenmiştir. Çalışmada LES türbülans modeli kullanılmış ve farklı türbülans şiddetlerinde çok büyük farklılıkların görülmediği gözlemlenmiştir.

$\mathrm{Bu}$ çalışmada, yerleşim alanları içerisindeki farklı sayıda binaların akış yapıları incelenmiştir. Tek bina ve aralarında $0,5 \mathrm{H}$ mesafe bulunan yan yana iki bina için analizler yapılmıştır. Sayısal çözümlemeler FLUENT programı ile hesaplanmış 
olup, akım çizgileri, hız vektörleri, hız dağılımı, türbülans kinetik enerji dağılımı ve bina yüzeylerindeki basınç katsayıları dağılımları elde edilmiştir.

\section{MODEL VE SAYISAL YÖNTEM}

Çalışmada kullanılan bina modeli ve boyutları Sivas ilinde tamamlanmış 12 katlı ve 48 daireden oluşan bina ölçülerine göre oluşturulmuştur. 120 $\mathrm{mm}$ ve $100 \mathrm{~mm}$ kesitine ve $160 \mathrm{~mm}$ yüksekliğinde (H) tek bina modeli ile aynı ölçülere sahip $S_{1}$ ara mesafesinde yan yana konumlandırılmış iki bina modeli Şekil 1'de gösterilmiştir. Bina boyutları, karşılaştırma yapılan deneysel ve sayısal çalışmada kullanılan bina model ölçeğine göre 1/250 oranda küçültülerek oluşturulmuştur.

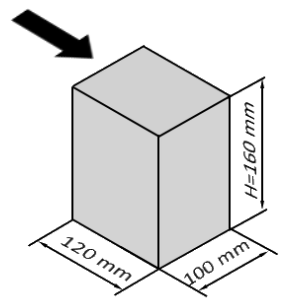

a)

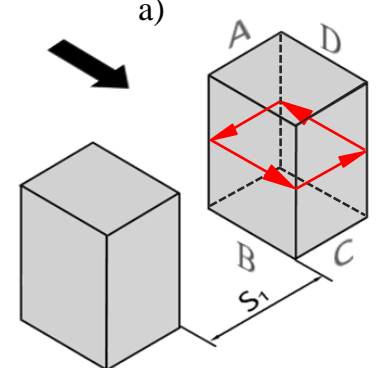

b)

Şekil 1. Bina modelleri a) Tek bina b) Yan yana iki bina modeli

Binalar, akıș alanı içerisine akış alanının ön bölgesinden $5 \mathrm{H}$, yan duvarlardan $5 \mathrm{H}$ ve çıkış bölgesinden $15 \mathrm{H}$ mesafesinde yerleştirilmiştir. Çalışmada, 20 yıllık meteoroloji verilerinden rüzgâr hızının Sivas ili için ortalama değeri $12 \mathrm{~m} / \mathrm{s}$ olarak belirlenmiş ve engel yüksekliğine bağlı Reynolds sayısı 179.000 olarak hesaplanmıştır. Ortalama hız ve türbülans profilleri akış alanında giriş sınır şartı olarak verilmiştir.

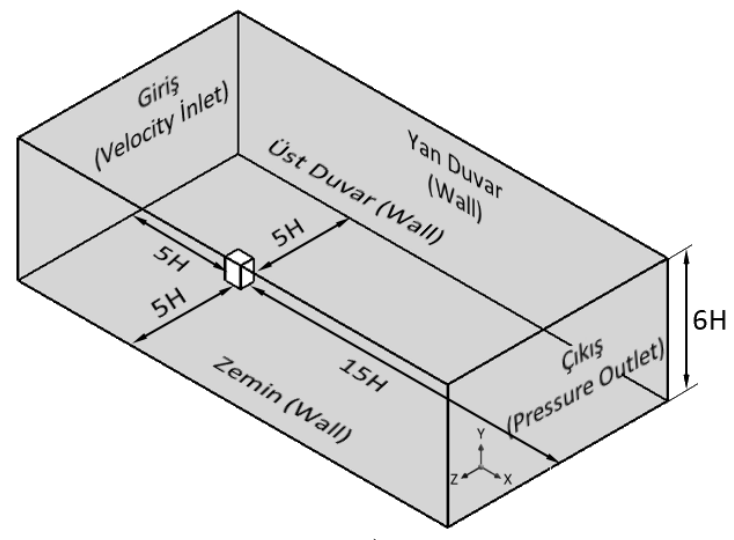

a)
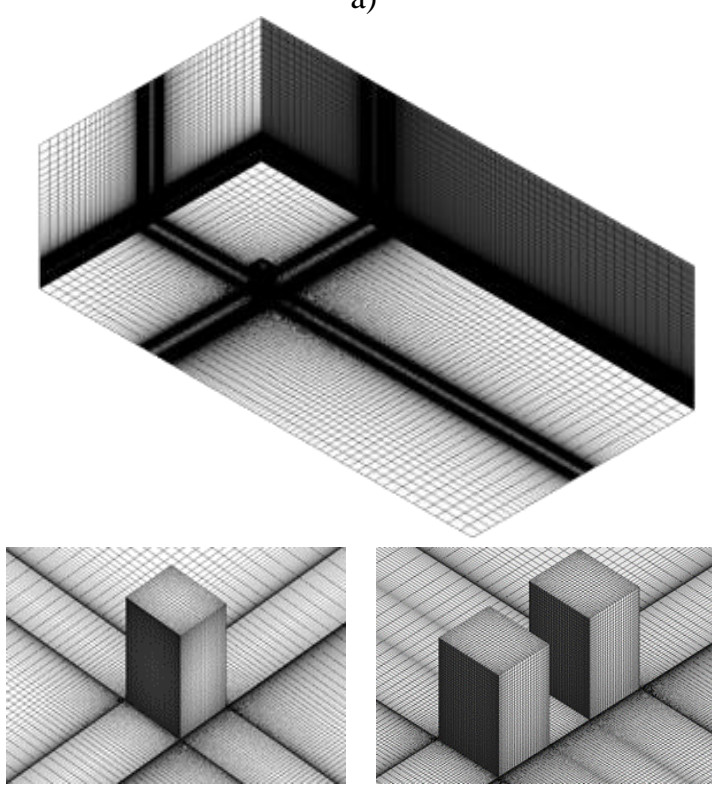

b)

Şekil 2. a) Akıș alanı boyutları b) Tek bina ve yan yana iki bina modelinin ağ yapısı

Bina modeli etrafındaki üç boyutlu akış alanının sayısal çözümleri, ANSYS - FLUENT 14.0 paket programı kullanılarak gerçekleştirilmiştir. Belirlenen modellere uygunluğu, kolay oluşturulabilmesi ve çözülebilmesi gibi avantajlarından dolayı ağ elemanı olarak dörtgensel eleman kullanılmıştır. Tek bina için 2700000, yan yana iki bina modeli için 3400000 elemandan oluşan ağ yapısının yeterli olacağı farklı eleman sayılarına sahip çözümlerle karşılaştırılarak tespit edilmiştir (Şekil 2). 
A $\breve{g}$ yapısı oluşturulurken değişimin hızlı olması beklenilen ve asıl inceleme alanı olan bina yakınındaki bölgelerde daha sık bir ağ yapısı oluşturularak çözümün hassasiyeti artırılmıştır. Türbülans modeli olarak RNG $\mathrm{k}-\varepsilon$ türbülans modeli, duvar yaklaşımı olarak Standart Duvar Fonksiyonu (Standard Wall Function) esas alınmıştır.

\section{SAYISAL SONUÇLAR}

Kullanılan sayısal yöntem ile elde edilen sonuçların doğruluğunu belirleyebilmek için, literatürdeki deneysel ve sayısal çalışmalardan elde edilen sonuçlarla karşılaştırma yapılmıştır. Şekil 3'de binanın orta yüksekliğindeki tüm yüzeylerinde basınç katsayılarının $\left(\mathrm{C}_{\mathrm{p}}\right)$ değişimi yapılan çalışmadan elde edilen sonuçlarla uyumlu olduğu görülmektedir.

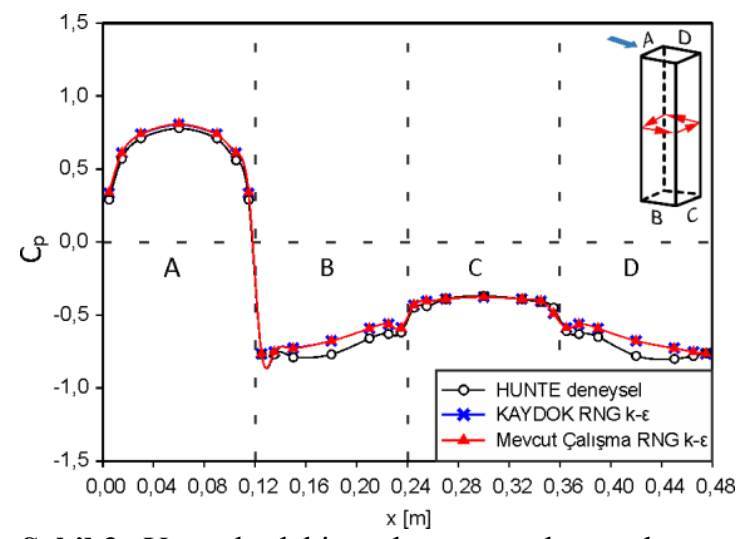

Şekil 3. Yüzeylerdeki basınç katsayılarının deneysel ve sayısal çalışma ile karşılaştırılması

Çalışmadan elde edilen sonuçlar, binanın orta $(\mathrm{y}=0,08 \mathrm{~m})$ hem de model yüksekliğinde $(\mathrm{y}=0,16 \mathrm{~m})$ yatay doğrultuya ait akım çizgileri, hız vektörleri, hız dağılımı ve türbülans kinetik enerji dağılımları olarak gösterilmiştir. Ayrıca her iki modelin bina yüzeylerinde hesaplanan basınç katsayıları dağılımı ve bina yüksekliği ile basınç katsayısı değişimi grafiksel olarak da gösterilmiştir.

Şekil 4'de tek bina modeli için hesaplanan akım çizgileri, hız vektörleri, hız dağılımı ve türbülans kinetik enerji değişimleri gösterilmektedir. Şekil 4a'da model yarı yüksekliğinde binanın ön yüzeyine gelen akış, durma noktasından itibaren yukarı ve aşağı yönlenerek modelin ön köşelerinden ayrılmakta ve akışa paralel durumdaki yan yüzeyler üzerinde küçük ölçekli girdap bölgeleri oluşturmaktadır. Akış ayrılmasının sebebi, ayrılma noktalarında kinetik enerjinin, basınç enerjisine göre düşük yoğunlukta kalmasıdır. Yukarı ayrılan akış, model arkasında akışa paralel yan yüzey üzerinde oluşturduğu girdap ile birleşen saat yönünde dönen girdab1, aşağ 1 ayrılan akış ise model arkasında akışa paralel yan yüzey üzerinde oluşturduğu girdap ile birleşen saat yönünün tersinde dönen girdabı oluşturmuştur. Oluşan girdaplar birbirine göre simetriktir. Model yüksekliğinde $(\mathrm{y}=0,16 \mathrm{~m})$, ön yüzeyine gelen akış durma noktasından itibaren yukarı ve aşağı yönlenmekte ve modelin ön köşelerinden ayrılmaktadır. Bina yan yüzeyine tutunan akış, girdap oluşturmadan devam etmektedir. Şekil 4b'de hiz vektörleri model yarı yüksekliğinde bina yan yüzeylerinde ve bina iz bölgesinde hızın azalması nedeniyle vektör boylarında küçülmenin olduğu ve iz bölgesinden uzaklaştıkça vektör boylarının büyüdüğü görülmektedir. Bina yan yüzey ve iz bölgesinde ise ters akış sebebi ile akış yönünün tersi yönlü vektörler oluşmaktadır. Model yüksekliğinde ise hız vektörlerinin boyları model iz bölgesinde küçülmekte, akış yönünde ilerleyen kısımlarda normale dönmektedir. Şekil 4c'de model yarı yüksekliğinde, bina yan yüzeylerinde türbülanslı akışın olduğu, iz bölgesinde hızın azaldığı ve ters akış bölgelerinin oluştuğu görülmektedir. Maksimum hız bina yan yüzeyleri üzerinde oluşmaktadır. Model yüksekliğinde, yan yüzeyleri üzerinde model yarı yüksekliği seviyesine göre daha büyük maksimum hız alanını oluşmuştur. İz bölgesinde hızın azaldığı ancak bu azalma model yarı yüksekliğine oranla daha az olduğu görülmektedir. Şekil 4d'de binanın ön köşeleri ve bina yan yüzeyleri üzerinde türbülans kinetik enerjinin en yüksek değerlerde olduğu, ayrıca binanın arkasından uzaklaştıkça artmaya başladığı gözlenmektedir. Model yüksekliği seviyesinde türbülans kinetik enerjinin en büyük değerlerine akış ayrılmasının olduğu model ön yüzey bölgesinde ulaştığı görülmektedir. 

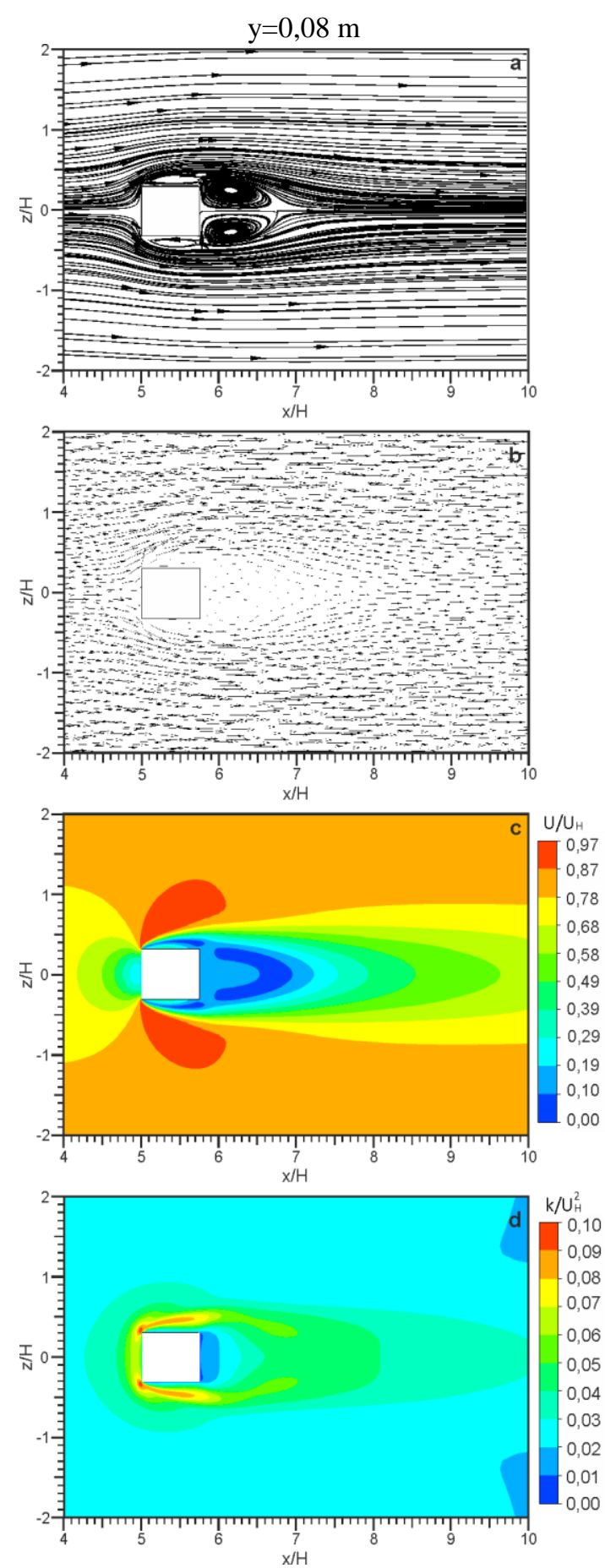
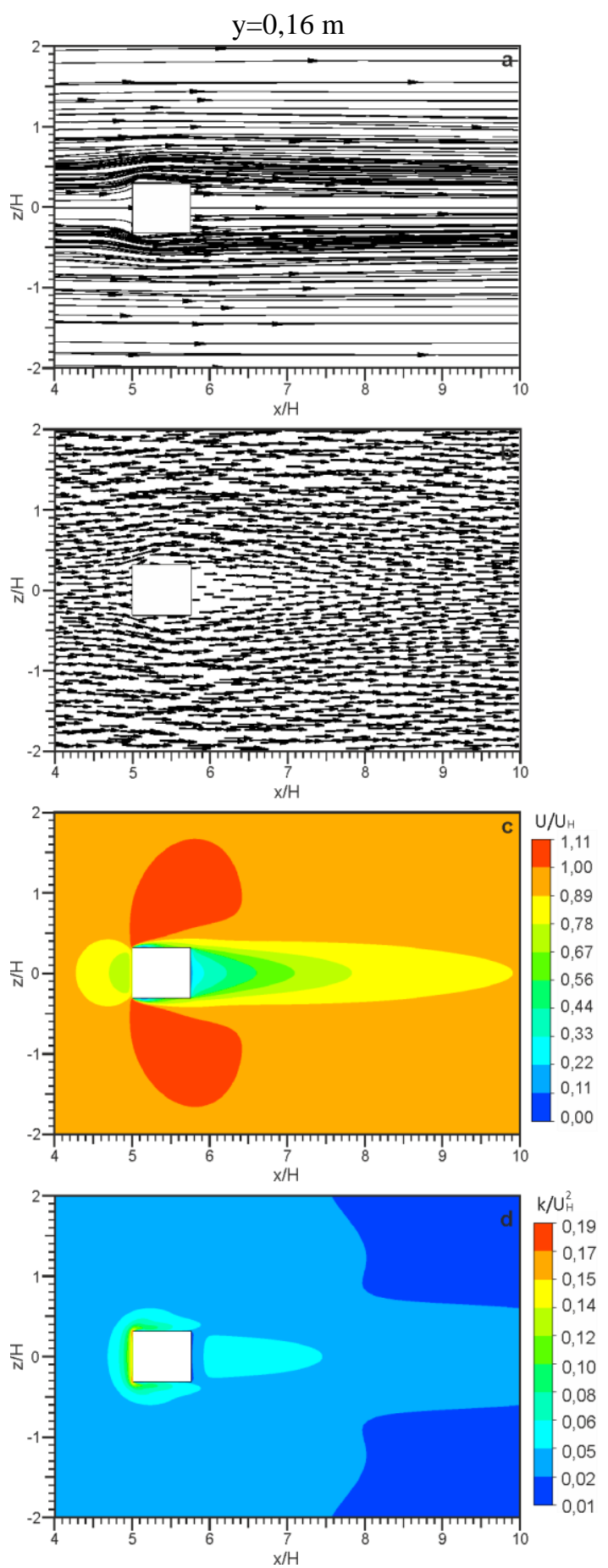

Şekil 4. Tek binanın orta ve model yüksekliğinde $(y=0,08 \mathrm{~m}-\mathrm{y}=0,16 \mathrm{~m})$ yatay doğrultuya ait a) akım çizgileri b) hız vektörleri c) hız dağılımı d) türbülans kinetik enerji dağılımı 


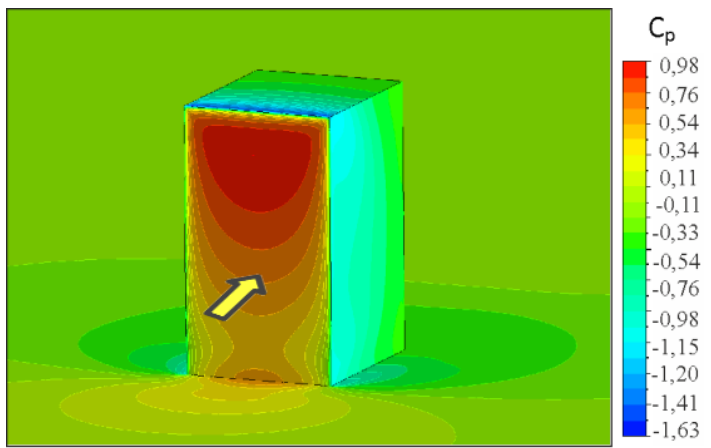

Şekil 5. Tek bina modelinin yüzeydeki basınç katsayısı dağılımı

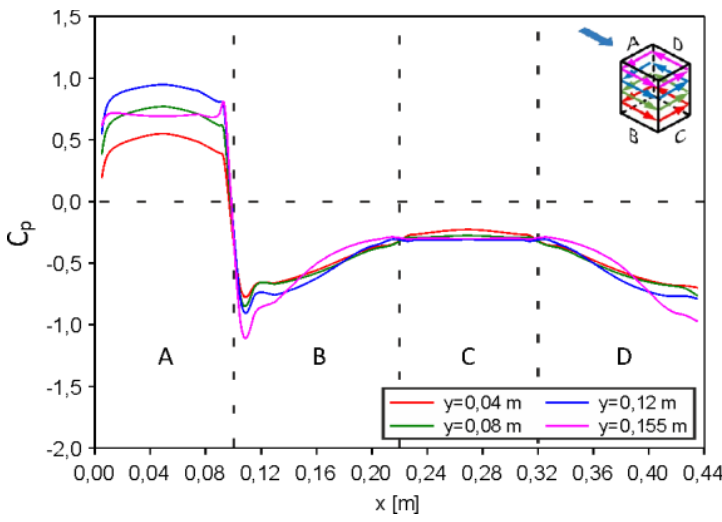

Şekil 6. Tek bina modelinin yatay doğrultuda farklı yüksekliklerde yüzeylerin basınç katsayıları dağılımları

Tek bina modelinin yüzeyleri için hesaplanmış basınç dağılımları Şekil 5'de ve yatay düzlemde farklı yüksekliklerde hesaplanan basınç dağılımları Şekil 6'da verilmiştir. Rüzgara doğrudan maruz kalan ön (A) yüzeyde, basınç katsayıları pozitif değerler almaktadır. Ön yüzeyde yüksekliğin artmasına bağlı olarak basınç katsayılarının arttığı, ancak model yüksekliğine yakın yükseklik $(\mathrm{y}=0,155 \mathrm{~m})$ için basınç katsayıları azalmıştır. Binanın sağ (B), arka (C) ve sol (D) yüzeylerinde ise negatif basınç katsayılarının oluştuğu, yan yüzeylerde (B, D) oluşan negatif basınç katsayılarının arka yüzeyde oluşan negatif basınç katsayılarından daha yüksek olduğu görülmektedir. Şekil 7'de yan yana iki bina modeli için hesaplanan akım çizgileri, hız vektörleri, hız dağılımı ve türbülans kinetik enerji değișimleri gösterilmektedir. Şekil 7a'da yukarıdaki binanın ön üst köşesinden ayrılan akış, binanın üst yan yüzeyinde saat yönünde dönen küçük girdabı ve bina arkasında saat yönünde dönen yan yüzey üzerindeki girdap ile bileşen daha büyük girdabı oluşturmuştur. Binanın ön alt köşesinden ayrılan akış, iki bina arası bölgede hem jet akışı hem de yan yüzeyde girdap oluşturmakla birlikte, bina arkasında saat yönünün tersinde dönen ve bina arkasındaki diğer girdaba göre daha büyük olan başka bir girdabı oluşturmaktadır. Aşağıdaki binanın ön üst köşesinden ayrılan akış, yan yüzeyi yüzeyinde girdap oluşturmamış bina arkasında saat yönünde dönen ve bina arkasındaki diğer girdaba göre daha büyük girdabı oluşturmuştur. Ön alt köşesinden ayrılan akış, yan yüzeyinde saat yönünün tersinde dönen küçük girdabı ve bina arkasında yan yüzey üzerindeki girdap ile bileşen yan yüzey üzerindeki girdaptan daha büyük girdabı oluşturmuştur. Bina model yüksekliğinin $(\mathrm{y}=0,16 \mathrm{~m})$ akım çizgileri incelendiğinde binaların ön köşelerinden ayrılan ve yan yüzeylerine tutunan akışın girdap oluşturmadığı görülmektedir. Şekil 7b'de hız vektörlerinde iki bina arası bölgede hız vektörlerinin boyutunun büyüdüğü, diğer yan yüzeylerde akım yönünün tersi yönlü vektörlerin olduğu gözlemlenmektedir. Model yüksekliği seviyesinde, modellerin arka iz bölgesinde vektör boylarının küçüldüğü akış yönünde ilerleyen konumlarda hızın arttığı görülmektedir.

Şekil 7c'de hız dağılımında, binalar arasında jet akış sebebi ile maksimum hızın oluştuğu, binaların diğer yan yüzeyleri yakınlarında ve iz bölgesinde hızın azaldığı görülmektedir. Model yükseklinin hız dağılımı incelendiğinde, bina yan yüzeyleri yakınlarında yine maksimum hızın oluştuğu ve iz bölgesinde azalmanın olduğu ancak bu azalma modellerin yarı yüksekliğine oranla daha az olduğu görülmektedir. Şekil 7d'de model yar1 yüksekliğinde türbülans kinetik enerji, binaların karşılıklı ön köşelerinde ve yan yüzeylerinde türbülans kinetik enerji en yüksek değerlerdedir. Modellerin yüksekliği seviyesinde türbülans kinetik enerjinin en büyük değerleri akış ayrılmasının olduğu model ön bölgesinde oluşmuştur. Model yüksekliği seviyesinde türbülans kinetik enerjinin yüksek değerlerde olması serbest akış ve ters akış bölgesi arasındaki karışım bölgesinin olduğunu göstermektedir. 

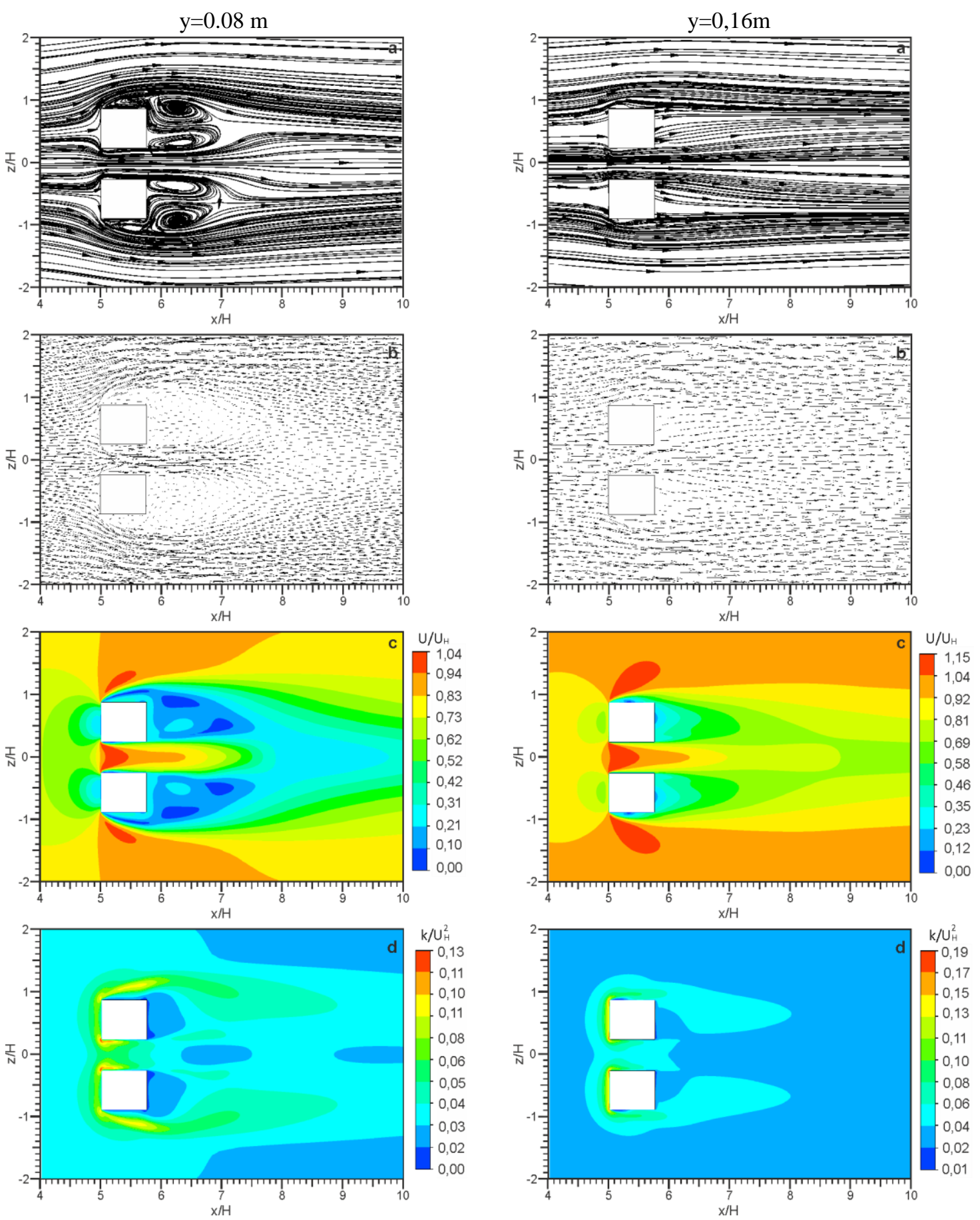

Şekil 7. $\mathrm{S}_{1}=0,5 \mathrm{H}$ ara mesafeli ikili binanın orta ve model yüksekliğinde ( $\left.\mathrm{y}=0,08 \mathrm{~m}-\mathrm{y}=0,16 \mathrm{~m}\right)$ yatay doğrultuya ait a) akım çizgileri b) hız vektörleri c) hız dağılımı d) türbülans kinetik enerji dağılımı 


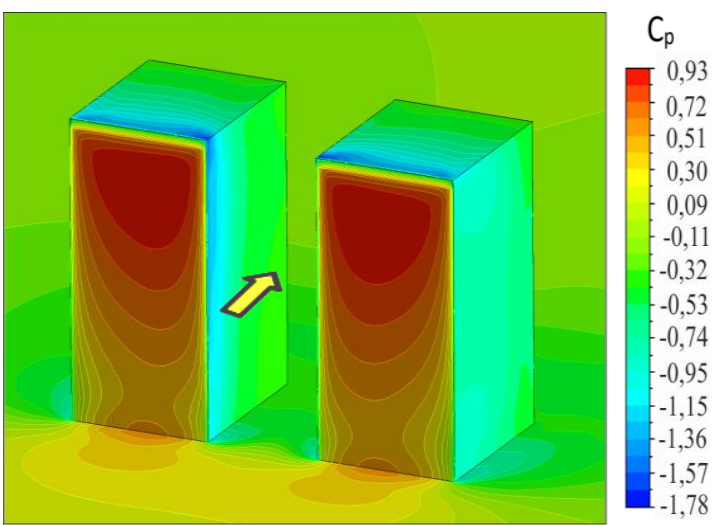

Şekil 8. $S_{1}=0,5 \mathrm{H}$ ara mesafeli ikili bina modelinin yüzeydeki basınç katsayısı dağılımı

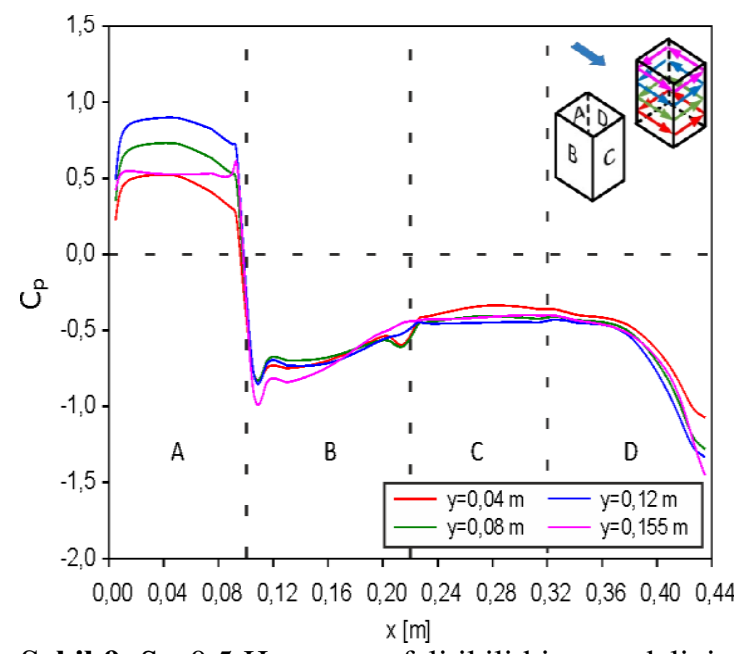

Şekil 9. $\mathrm{S}_{1}=0,5 \mathrm{H}$ ara mesafeli ikili bina modelinin yatay doğrultuda farklı yüksekliklerde yüzeylerin basınç katsayıları dağılımları

$\mathrm{S}_{1}=0,5 \mathrm{H}$ ara mesafeli iki bina modelinin yüzeyleri için hesaplanmış basınç dağılımları Şekil 8'de gösterilmektedir. Basınç dağılımlarının bina ön yüzeyinde pozitif olduğu, çatı başlangıcında ise en yüksek negatif basınç kat sayısı oluşmuştur. $\mathrm{y}=0,04 \mathrm{~m}, \mathrm{y}=0,08 \mathrm{~m}, \mathrm{y}=0,12 \mathrm{~m}$ ve $\mathrm{y}=0,155 \mathrm{~m}$ yüksekliklerdeki basınç dağılımlarında (Şekil 9) ön yüzeyde yüksekliğin artmasına bağlı olarak pozitif basınç katsayılarının arttığı, fakat model yüksekliğine yakın yükseklikte $(\mathrm{y}=0,155 \mathrm{~m})$ basınç katsayısının azaldığı görülmektedir. Binanın sağ (B), arka (C) ve sol (D) yüzeylerinde ise negatif bir basınç alanının oluştuğu görülmektedir. Model yan yüzeylerinde (B, D) oluşan negatif basınç katsayılarının, arka yüzeyde oluşan negatif basınç katsayılarından daha yüksek oluşmaktadır. Model ön yüzeyinin köşelerinden ayrılan akış nedeniyle, yan yüzeylerdeki ayrılmış akış bölgelerinde negatif pik basınç katsayısı değerleri meydana gelmektedir. Ön (A) yüzey dişında, diğer yüzeyler için yükseklik değişimi sonucu basınç katsayısı yaklaşık olarak aynıdır.

\section{SONUÇ}

$\mathrm{Bu}$ çalışmada, tek ve yan yana iki bina üzerine gelen rüzgârın bina yüzeyleri üzerindeki etkileri sayısal olarak incelenmiştir. Bina model yarı yüksekliği ve model yüksekliği seviyelerinde akım çizgileri, hız vektörleri, hız ve türbülans kinetik enerji dağılımları ile model yüzeylerinin basınç katsayıları hesaplanmıştır. Her iki analiz sonucunda binanın doğrudan rüzgâra maruz kalan ön yüzeylerinde pozitif basınç katsayılarının olduğu gözlemlenmiştir. Binanın yan ve arka yüzeylerinde ise negatif basınç katsayıları değerleri yer almaktadır. Oluşan negatif en yüksek basınç $\mathrm{S}_{1}=0,5$ ara mesafeli yan yana konumlandırılan iki binada oluşmuştur. İkili bina modelinde basınç dağılımları birbirine simetrik olup, en yüksek negatif basınç katsayıları, bina ara bölgesi kısmının ön köşe noktalarında oluşmuştur. Ayrıca çatı ön kısmı ile karşılıklı yüzeylerin (sağdaki binanın $\mathrm{D}$ yüzeyi ile soldaki binanın B yüzeyi) ön köşe bölgesinde negatif basınç katsayılarının yüksek olduğu görülmektedir. Çalışma sonucunda elde edilen bulgular sonucunda, bina yapım aşamasında bölgenin hâkim rüzgâr yönünün belirlenmesini ve bina cephesinde özellikle çatıya yakın bölümlerde oluşan rüzgâr yükünün olumsuz etkilerini azaltılmasının önemli olduğunu ortaya koymaktadir.

\section{TEŞEKKÜR}

$\mathrm{Bu}$ çalışma, Cumhuriyet Üniversitesi Bilimsel Araştırma Projeleri (CÜBAP) birimi tarafindan M-611 numaralı proje ile desteklenmiştir. Desteklerinden dolayı CÜBAP birimine teşekkürlerimizi sunarız. 


\section{KAYNAKLAR}

1. Blocken, B., Carmeliet, J., Stathopoulos, T., 2007. CFD Evaluation of Wind Speed Conditions in Passages Between Parallel Buildings - Effect of Wallfunction Roughness Modifications for the Atmospheric Boundary Layer Flow, Journal of Wind Engineering and Industrial Aerodynamics, 95, 941-962.

2. Özmen, Y., Baydar E., Van Beeck J.P.A.J., 2016. Wind Flow Over the Low-Rise Building Models with Gabled Roofs Having Different Pitch Angles. Building and Environment, 95, 63-74.

3. Kaydok, T., 2014. Farklı Kesitlere Sahip Yüksek Binalar Üzerinde Türbülanslı Akışların Sayısal İncelenmesi. K.T.Ü. Fen Bilimleri Enstitüsü (Yüksek Lisans Tezi), Trabzon 94.

4. Hunte, S., 2010. Testing the Application of CFD for Building Design. Delft University of Technology (Master Thesis), Netherland.

5. Tutar, M., Oğuz, G., 2002. Large Eddy Simulation of Wind Flow Around Parallel Buildings with Varying Configurations. Fluid Dynamics Research, 289-315.

6. Kanbur, B.B., Pınarbaşı, A., Koca, A.İ., 2015. Aynı Bölgede Bulunan Yüksek ve Alçak Katlı Binalar Üzerindeki Rüzgar Yükleri Etkisinin İncelenmesi. Tesisat Mühendisliği, 146, $30-41$.

7. Gousseau, P., Blocken, B., Stathopoulos, T., 2011. CFD Simulation of Nearfield Pollutant Dispersion on a High Resolution Grid: A Case Study by LES and RANS for a Building Group in Downtown Montreal. Atmospheric Environment, 45, 428-438.

8. Braun, A.L., Awruch, A.M., 2009. Aerodynamic and Aeroelastic Analyses on the CAARC Standard Tall Building Model Using Numerical Simulation. Computers and Structures, 87, 564-581.

9. Nozawa, K., ve Tamura, T., 2002. Large Eddy Simulation of the Flow Around a Low Rise Building Immersed in a Rough-wall Turbulent Boundary Layer. Journal of Wind Engineering and Industrial Aerodynamics, 90, 1151-1162.

10. ANSYS 14, 2011. User Guide. 
